\section{Tinjauan Pustaka}

\section{TERAPI IMUNOLOGI PADA MELANOMA}

\author{
Muhamad Addin Syakir ${ }^{1}$, Dwi Indria \\ Anggraini $^{2}$ \\ ${ }^{1}$ Program Studi Profesi Dokter, Fakultas \\ Kedokteran, Universitas Lampung \\ 2Departemen Ilmu Penyakit Kulit dan Kelamin, \\ Rumah Sakit Dr. H. Abdoel Moeloek - Fakultas \\ Kedokteran, Universitas Lampung
}

\begin{abstract}
ABSTRAK
Pendahulan: Imunoterapi untuk kanker digunakan berdasarkan prinsip penyakitnya bahwa sistem kekebalan tubuh mampu menghasilkan respons imun terhadap sel-sel tumor. Saat ini tatalaksana yang tersedia untuk pasien melanoma selektif berdasarkan tingkat respons dari penyakitnya.

Metode: Artikel ini disusun menggunakan metode literature review, menggunakan 32 sumber berasal dari jurnal dan buku hasil literature searching dari search engine (Google dan Google Scholar) dan electronic source of database (PubMed, MeSH, Medline, dan SCOPUS).

Hasil: Interferon- $\alpha$ telah disetujui untuk pengobatan ajuvan stadium III melanoma dengan peningkatan survival rate. Diperlukan pendekatan baru dan lebih inovatif dengan peningkatan efek terapi. Prognosis pasien dengan melanoma metastasis di dunia telah berubah secara dramatis sejak adanya imun checkpoint inhibitor. Ipilimumab, yang menargetkan protein cytotoxic T lymphocyte-associated protein 4 (CTLA-4) adalah agen pertama yang ada. Selanjutnya nivolumab dan pembrolizumab yang berikatan dengan protein programmed death protein 1 (PD-1) telah terbukti lebih efektif dan lebih rendah angka toksisitasnya daripada ipilimumab. Kombinasi nivolumab atau pembrolizumab dengan ipilimumab telah menghasilkan peningkatan tingkat respons dan hasil survival rate pasien. Tinjauan pustaka ini akan mengeksplorasi data uji klinis penting yang telah menyebabkan penggunaan agen imunoterapi ini di dunia dan beberapa hasil uji klinis yang saat ini dilaporkan untuk terapi kombinasi baru.
\end{abstract}

Simpulan: Saat ini terapi imunologi untuk tatalaksana melanoma dapat di terapkan.

Kata kunci: Imunoterapi, kanker kulit, melanoma, tatalaksana

\title{
IMMUNOLOGICAL THERAPY IN MELANOMA
}

\begin{abstract}
Introduction: Immunotherapy for cancer is used based on the principle of the disease that the immune system is able to produce an immune response to tumor cells. Treatment is currently available for selective melanoma patients based on the response rate of the disease.

Methods: This article was compiled using the literature review method, using 32 sources derived from journals and books resulting from literature searching from search engines (Google and Google Scholar) and electronic sources of databases (PubMed, MeSH, Medline, and SCOPUS).

Results: Interferon- $\alpha$ was approved for the treatment of adjuvant stage III melanoma with increased survival rate. New and more innovative approaches are needed with increasing therapeutic effects. The prognosis of patients with metastatic melanoma in the world has
\end{abstract}


changed dramatically since the presence of an immune checkpoint inhibitor. Ipilimumab, which targets the cytotoxic T lymphocyte-associated protein 4 (CTLA-4) protein, is the first agent that exists. Furthermore, nivolumab and pembrolizumab that bind to programmed death protein $1(P D-1)$ proteins have been shown to be more effective and lower in toxicity than ipilimumab. The combination of nivolumab or pembrolizumab with ipilimumab has resulted in increased response rates and patient survival rate results. This literature review will explore important clinical trial data that have led to the use of this immunotherapy agent in the world and some clinical trial results currently reported for new combination therapies. Conclusion: At present immunology therapy for melanoma management can be applied.

Keywords: Immunotherapy, management, melanoma, skin cancer.

\section{PENDAHULUAN}

Terapi kanker secara imunologi merupakan merevolusi pengobatan kanker yang terbaru dan banyak hasil yang baik yang dilaporkan di berbagai macam keganasan. Melanoma maligna salah satu kanker yang menjadi sorotan akhir-akhir ini dalam terapi imunologi. Melanoma maligna adalah neoplasma (tumor ganas) kulit yang paling banyak menimbulkan kematian di Amerika Serikat dan Eropa dengan jumlah insiden yang masih terus meningkat. Di Indonesia, menurut data histopatologis penelitian Muhartono tahun 2017, kanker kulit merupakan salah satu kanker dari tiga kanker yang paling sering ditemui. Melanoma maligna menempati urutan ke-5 pada laki laki dan urutan ke 7 pada wanita dari keganasan yang sering ditemukan. Melanoma maligna menyumbang $1-2 \%$ dari semua kematian akibat kanker. ${ }^{[1]}$

Meskipun melanoma lebih sering didiagnosis pada orang tua, namun dapat juga terbentuk pada orang yang lebih muda. Lebih dari 900 orang dewasa berusia di bawah 35 terdiagnosis dengan melanoma setiap tahun di Inggris, dan ini merupakan adalah kanker paling sering terjadi kedua pada orang dewasa yang berusia antara 25 dan 49 tahun. Oleh karena itu, melanoma menyebabkan angka mortalitas yang meningkat daripada kanker lain. Kebanyakan melanoma terjadi pada orang dengan kulit pucat. Faktor risiko lain adalah kulit yang cenderung terbakar di bawah sinar matahari, memiliki banyak tahi lalat, terpapar sinar matahari yang intermiten dan sering terbakar sinar matahari. [2]

Melanoma ganas dengan mudah didefinisikan sebagai neoplasma ganas yang berasal dari sel melanosit.
Sebagian besar melanosit berada di kulit di lapisan basal epidermis, dipisahkan oleh keratinosit. Bagian tubuh lain yang terdapat melanosit mungkin saja dapat terjadi melanoma contohnya saluran uveal mata dan berbagai permukaan mukosa, seperti mukosa sinonasal, mukosa mulut, dan vulva. ${ }^{[3]}$

Sampai saat ini tatalaksana yang tersedia untuk pasien dengan melanoma masih terbatas. Pada pasien dengan metastasis, kemoterapi, terapi biologik (mis. Interleukin 2 [IL-2], limfosit yang menginfiltrasi tumor, dan kombinasi biokemoterapi telah menghasilkan tingkat respons rendah sekitar 20\% hingga $30 \%$. Untuk pasien yang berisiko tinggi dengan kasus relaps, pengobatan dengan interferon $\alpha 2 b$ (IFN- $\alpha$ ) dalam terapi ajuvan telah terbukti meningkatkan survival bebas penyakit dibandingkan dengan observasi saja pada pasien dengan stadium Ilb atau stadium III. Diperlukan pendekatan baru dan inovatif serta terapi yang lebih efektif untuk terapi melanoma. Salah satu pendekatan yang menjanjikan adalah terapi imunoterapi. ${ }^{[4]}$

\section{METODE}

Tinjauan pustaka ini dicari menggunakan metode literature searching. Literature searching menggunakan bantuan search engine (Google dan Google Scholar) dan electronic source of database (PubMed, $\mathrm{MeSH}$, Medline, dan SCOPUS). Studistudi berbahasa Inggris yang diterbitkan antara tahun 2014 hingga 2019. Istilah dalam pencarian termasuk: patient care team, patient care planning, primary nursing care, case management, critical pathways, guidelines, practice guidelines, disease management, comprehensive health care, dan 
ambulatory care yang berhubungan dengan terapi imunologi pada melanoma. Setelah pencarian, didapatkan 32 sumber pustaka yang berasal dari jurnal maupun buku.

\section{PEMBAHASAN}

Tatalaksana awal dari banyak kasus melanoma yaitu pembedahan, karena sebagian besar melanoma dapat disembuhkan dengan eksisi lokal yang luas. Namun, jika pada pasien terdapat penyebaran yang luas, obat sistemik diperlukan. Di masa lalu, agen kemoterapi tradisional tidak banyak memperbaiki survival dari seseorang dengan melanoma. Di antara obat-obat kemoterapi yang ada, dacarbazine merupakan obat yang paling efektif. Penjelasan yang lebih dalam tentang patogenesis melanoma, menjadikan semakin banyak pilihan pengobatan. Obat-obatan baru dapat bekerja melalui dua mekanisme: obat yang menargetkan perubahan jalur yang disebabkan oleh mutasi gen ("targeted therapy ") atau obat yang menambah sistem kekebalan tubuh untuk melawan kanker ("imunoterapi").[5]

\subsection{Targeted therapy}

Kunci terapi melanoma yang ditargetkan berputar di sekitar jalur mitogen-activated protein (MAP) kinase (Gambar. 1). Sebagai pengatur proliferasi sel, aktivasi dari jalur MAP kinase dapat menyebabkan perkembangan melanoma. ${ }^{[6]}$ Sekitar 40$60 \%$ melanoma mengandung mutasi aktif pada BRAF. Sebagian besar melanoma mengaktifkan mutasi yang

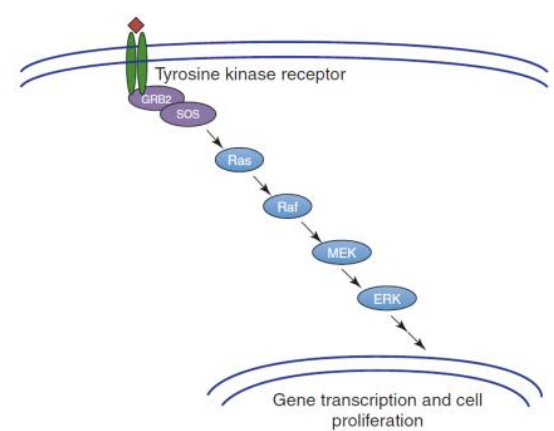

Gambar 1. Jalur MAP kinase. Aktivasi reseptor tirosin kinase memulai kaskade yang menghasilkan proliferasi sel.[5] menyebabkan perubahan pada kodon 600 dari valin menjadi asam glutamat (BRAF V600E). ${ }^{[7]}$

Vemurafenib dan dabrafenib merupakan obat kemoterapi penghambat mutasi BRAF dan karena itu digunakan untuk mengobati melanoma. Dalam percobaan fase III, vemurafenib dibandingkan dengan dacarbazine pada 675 pasien dengan kanker stadium IIlc atau stadium IV yang tidak diobati. Survival pasien dihitung pada bulan ke-6 dan ditemukan $84 \%$ untuk vemurafenib dan $64 \%$ untuk dacarbazine. Survival secara keseluruhan dan survival bebas dari perkembangan penyakit adalah 13,6 dan 9,7 bulan untuk vemurafenib dibandingkan 5,3 dan 1,6 bulan untuk dacarbazine. Efek samping yang paling sering ditimbulkan adalah efek samping grade 1-2 seperti artralgia (50\%), kelelahan (43\%), fotosensitifitas (37\%), dan ruam (32\%). Efek samping grade 34 yang lebih parah yang terjadi yaitu kanker kulit sel skuamosa (SCC) (19\%), keratoacanthomas (KA) (10\%), ruam $(9 \%)$, dan tes fungsi hati abnormal (11\%). [7] Meskipun jarang, perlu dicatat bahwa vemurafenib dapat menyebabkan perpanjangan $\quad$ QT $\quad$ pada elektrokargiografi. ${ }^{[8]}$

Dalam uji coba fase III, dabrafenib dibandingkan dengan dacarbazine pada 250 pasien dengan melanoma stadium III atau stadium IV yang tidak diobati. Survival rate secara keseluruhan lebih baik dabrafenib tetapi tidak signifikan secara statistik. Survival bebas dari berkembangnya penyakit adalah 5,1 bulan untuk dabrafenib dibandingkan 2,7 bulan untuk dacarbazine. Efek samping grade 2 yang paling sering terjadi adalah hiperkeratosis $(12 \%)$, eritrodisestesia palmar-plantar $(6 \%)$, pireksia $(8 \%)$, dan kelelahan (5\%). Kejadian efek samping grade 3 atau 4 yang lebih parah jarang terjadi. SCC atau KA terjadi pada $2 \%$ atau 4\% untuk kelas 2 dan 3, masingmasing.

Sering terjadi adanya SCC dan KA pada pasien dengan kedua inhibitor BRAF. Kanker-kanker ini biasanya terbentuk tidak lama setelah dimulainya pengobatan dan biasanya ditatalaksana dengan pembedahan. Studi lebih lanjut menunjukkan bahwa pasien ini memiliki 
mutasi protein RAS yang sudah ada di kulit mereka. Ketika mengalami penghambatan BRAF, mutasi protein RAS ini secara paradoks meningkatkan sinyal pada pathway dan menyebabkan terjadinya SCC dan KA. ${ }^{[9]}$

Perkembangan obat inhibitor BRAF merupakan terobosan yang cukup besar, namun tidak efektif sebagai monoterapi, karena obat ini terdapat resistensi terhadap obat dalam membatasi survival dari perkembangan melanoma. Jalur MAP kinase diaktifkan kembali, biasanya difasilitasi melalui mutasi sekunder pada gen seperti RAS, BRAF, dan MEK.[10,11] Inhibitor MEK, seperti trametinib dan cobimetinib, memblokir jalur MAP kinase yang sama, tetapi lebih jauh ke bagian hilir pada jalurnya. Obat ini digunakan dalam kombinasi dengan inhibitor BRAF untuk melanoma positif-BRAF.[12]

Dalam percobaan fase III, trametinib dibandingkan dengan dacarbazine atau paclitaxel pada 322 pasien melanoma yang belum pernah menerima pengobatan inhibitor BRAF sebelumnya. Tingkat kelangsungan hidup secara keseluruhan (survival rate) pada bulan ke- 6 adalah $81 \%$ berbanding $67 \%$. Survival dengan bebas berkembangnya penyakit adalah 4,8 bulan untuk dabrafenib dibandingkan 1,5 bulan untuk dacarbazine. Efek samping yang paling umum adalah ruam, diare, kelelahan, dan edema. Efek samping lainnya termasuk masalah jantung seperti penurunan fraksi ejeksi atau disfungsi ventrikel dan masalah oftalmologis seperti perubahan penglihatan dan korioretinopati reversibel. Tidak ada SCC atau KA yang menjadi efek samping. ${ }^{[13]}$

Kombinasi BRAF dan MEK inhibitor menghasilkan peningkatan hasil yang baik. Cobimetinib dikombinasikan dengan vemurafenib versus vemurafenib saja telah terbukti meningkatkan survival rate rata-rata menjadi 22,3 bulan dari 17,4 bulan. Kelompok dengan kombinasi memiliki tingkat efek samping yang lebih tinggi, termasuk peningkatan gammaglutamyl transferase, creatine phosphokinase, dan alanine transaminase serta efek samping seperti demam dan dehidrasi. ${ }^{[14]}$ Trametinib dalam kombinasi dengan dabrafenib dibandingkan dengan monoterapi dengan inhibitor BRAF saja (baik dabrafenib atau vemurafenib) juga telah menunjukkan peningkatan survival rate dan survival dari tidak adanya perkembangan penyakit. Kombinasi trametinib dengan dabrafenib akan menyebabkan diare, menggigil, atau demam. ${ }^{[15]} \quad$ Terapi kombinasi menunjukkan secara signifikan lebih sedikit kejadian SCC atau KA daripada monoterapi BRAF.[16]

\subsection{Imunoterapi}

Strategi pengobatan lain yaitu mendorong sistem kekebalan tubuh dalam mengenali dan menghilangkan melanoma. Ketika antigen-presenting cell (APC) menampilkan protein intraseluler ke sel T, perlu ada sinyal costimulatory agar sel T menjadi aktif. Hal ini terjadi ketika molekul B7 berikatan dengan CD28 pada sel T. Jika sinyal penghambat dikirim mengakibatkan (adanya "checkpoint") sel T tidak jadi aktif. Ini dapat terjadi ketika molekul B7 pada APC berikatan dengan reseptor antigen limfosit $T$ sitotoksik (CTLA-4) pada sel $\mathrm{T}$ atau ketika cell death ligand (PD-L1) dari sel tumor mengikat cell death 1 receptor (PD-1) pada sel $\mathrm{T}$. Dasar dari imunoterapi adalah untuk mem-bypass checkpoint sistem imun ini sehingga sel-sel $T$ mengenali dan menargetkan sel-sel kanker dengan tepat. ${ }^{[17]}$

Ipilimumab merupakan obat yang bekerja sebagai antibodi monoklonal yang mengikat CTLA-4 dan telah disetujui dalam pengobatan melanoma yang metastasis dan sebagai terapi tambahan pada kasus berisiko tinggi. Satu percobaan fase III membandingkan ipilimumab plus dacarbazine versus dacarbazine saja menemukan tingkat survival rate pada tahun ke-5 18\% berbanding 9\%.[18] Sebuah analisis dengan jumlah pasien yang lebih besar pada tahun 1861 menemukan bahwa kelangsungan hidup keseluruhan ratarata adalah 11,4 bulan dan bahwa kurva kelangsungan hidup mencapai sekitar $21 \%$ setelah 3 tahun terlepas dari terapi sebelumnya. ${ }^{[19]}$ Efek samping dari ipilimumab yaitu mempengaruhi imunitas 
hingga $85 \%$. Efek samping yang terjadi yaitu pada grade 3 atau lebih termasuk diare, toksisitas hati, dan ruam. Sebagian besar kasus dapat diobati dengan imunosupresi, baik dengan kortikosteroid atau inhibitor TNF alpha. Bagain terpenting yaitu efek samping pengobatan ini tidak mempengaruhi respons tumor terhadap ipilimumab. ${ }^{[20]}$

Pembrolizumab dan nivolumab merupakan antibodi monoklonal yang mengikat PD-1. Sebuah penelitian yang membandingkan dua dosis berbeda dari pembrolizumab (2 $\mathrm{mg} / \mathrm{kg}$ atau $10 \mathrm{mg} / \mathrm{kg}$ ) dibandingkan dengan pengobatan kemoterapi menemukan tingkat survival pasien pada tahun ke-2 secara keseluruhan yaitu 36,38 , dan $30 \% .{ }^{[21]}$ Nivolumab telah dibandingkan dengan kemoterapi dalam uji fase 3 dan telah menunjukkan peningkatan survival rate secara keseluruhan $(73 \%$ vs $42 \%$ dalam satu studi).[22,23] Kenyataanya, penanda tumor yang terdapat pada PD-L1 akan memilikir respon lebih baik, tetapi beberapa tumor yang tidak memiliki PDL1 juga menunjukkan ada respon. ${ }^{[24]}$ Efek sampingnya juga berhubungan dengan kekebalan tubuh dan terjadi pada $71 \%$ pasien. Gejala paling sering muncul adalah kelelahan, diare, ruam, dan gatal-gatal.[25]

Inhibitor PD-1 saat ini merupakan checkpoint inhibitor yang paling efektif pada melanoma dibandingkan dengan inhibitor CTLA-4. Nivolumab memiliki tingkat survival 2 tahun yang lebih baik yaitu $55 \%$ berbanding $43 \%$ dengan efek samping yang lebih sedikit daripada ipilimumab.[26] Kombinasi pembrolizumab/ nivolumab dengan ipilimumab juga telah menunjukkan tingkat respons yang lebih baik, tetapi dengan efek samping yang lebih sering muncul dan lebih parah.[27] Lebih banyak penelitian yang meneliti pilihan kombinasi pengobatan berurutan dengan kedua jenis checkpoint inhibitor ini. Beberapa tumor resisten terhadap inhibitor PD-1, sehingga tidak ada respon atau bahkan munculnya relaps dengan pengobatan. Studi telah menunjukkan bahwa tingkat resisten tumor ini dapat bawaan $(60 \%)$ atau didapat (25\%). ${ }^{28,29]}$ Karena pengobatan melalui mekanisme ini masih baru, obat dan rejimen pengobatan baru kemungkinan akan berkembang. ${ }^{[30]}$

\subsection{Rekomendasi Pengobatan Saat Ini \\ dan Dosis}

Obat sistemik digunakan dalam pengobatan melanoma yang metastasis. Regimen dosis tercantum pada Tabel 1. Imunoterapi sebagai tatalaksana utama. Sebagian besar pasien mulai menggunakan inhibitor PD-1, mungkin dalam kombinasi dengan ipilimumab. Pengobatan diberikan sampai akhir penyakit dapat berkembang, efek samping yang tidak dapat ditoleransi, dan manfaat secara klinis akan terlihat. Jika tumor memiliki mutasi BRAF, regimen pengobatan dapat dialihkan ke BRAF dan MEK inhibitor, atau keduanya dapat ditambahkan imunoterapi. Radiasi untuk metastasis otak atau operasi paliatif juga dapat dilakukan. Penelitian sedang dilakukan untuk menentukan urutan prioritas tatalaksana dan kombinasinya untuk obat sistemik. ${ }^{[4]}$

Tabel 1. Obat Melanoma Metastatik yang Sering Digunakan ${ }^{[5]}$

\begin{tabular}{ll}
\hline Nama Obat & $\begin{array}{l}\text { Dosis } \\
\text { Frekuensi }\end{array}$ \\
\hline Vemurafenib & $960 \mathrm{mg}$ per oral \\
& sehari 2 kali \\
Dabrafenib & $150 \mathrm{mg}$ per oral \\
& sehari 2 kali \\
Cobimetinib & $60 \mathrm{mg}$ sekali sehari \\
& pada hari ke 1 \\
& hingga 21 dari \\
& setiap siklus 28 hari \\
Trametinib & 2 mg per oral sekali \\
& sehari \\
Ipilimumab & 3 mg/kg setiap 3 \\
& minggu selama \\
& empat dosis \\
& (penyakit \\
& metastasis) \\
& 10 mg/kg setiap 3 \\
& minggu untuk \\
& empat dosis, lalu \\
& setiap 12 minggu \\
& hingga 3 tahun \\
(terapi adjuvan)
\end{tabular}


Pembedahan telah lama menjadi andalan pengobatan untuk melanoma. Namun, fokus baru pada terapi adjuvant dan neoadjuvant sangat berkembang, target terapi dan imunoterapi menjadi pilihan saat ini. Untuk penyakit stadium III, terapi tambahan dengan ipilimumab atau interferon alfa sudah disetujui tetapi belum menjadi terapi rutin. Interferon alfa memiliki toleransi ke pasien yang buruk, dan pada uji klinis menunjukkan hasil yang kurang konsisten dalam pengobatan. Ipilimumab dosis tinggi dapat diberikan pada $10 \mathrm{mg} / \mathrm{kg}$ setiap 3 minggu selama empat dosis dan kemudian setiap 12 minggu hingga 3 tahun, namun memiliki efek samping yang signifikan. Terapi neoadjuvant untuk melanoma yang berisiko tinggi tidak disetujui, tetapi uji coba fase I dan II sedang dilakukan untuk nivolumab dengan atau tanpa ipilimumab dan dabrafenib plus trametinib. ${ }^{[31,32]}$

\section{SIMPULAN}

Terapi imunologi pada melanoma dapat menjadi terapi yang menjanjikan kedepannya. Perlu penelitian lebih lanjut dalam menguji obat baru, jadwal pemberian dosis yang berbeda, dan kombinasi obat yang sudah ada sebelumnya. Mengingat perkembangan yang baik dalam beberapa tahun terakhir, pengobatan melanoma cenderung berubah dengan cepat dengan harapan meningkatkan hasil dari kualitas hidup pasien.

\section{DAFTAR PUSTAKA}

1. Muhartono, Hanriko R. Sosialisasi Bahaya Kanker Kulit (Melanoma Maligna) dan Pemeriksaan Kesehatan Gratis Bagi Masyarakat di Kecamatan Kemiling Bandar Lampung Socialization of Skin Cancer Hazards ( Malignant Melanoma ) and Free Medical Checkup for Communities in Districts Ke. JPM Ruwa Jurai. 2017;3:81-4.

2. NICE. Melanoma: assessment and management. London; 2015.

3. Elder DE. Pathology of melanoma. Surg Oncol Clin N Am. 2015;24(2):229-37.

4. Coit DG, Thompson JA, Algazi A,
Andtbacka R, Bichakjian CK, Carson WE 3rd, et al. Melanoma, Version 2.2016, NCCN Clinical Practice Guidelines in Oncology. J Natl Compr Canc Netw. 2016 Apr;14(4):450-73.

5. Martin S, Lo R. Update in Immunotherapies for Melanoma. In: Biologic and Systemic Agents in Dermatology. New York: Springer International Publishing; 2018. p. 549-52.

6. Wellbrock C, Arozarena I. The complexity of the ERK/MAP-kinase pathway and the treatment of melanoma skin cancer. Front Cell Dev Biol. 2016;4(Apr):1-9.

7. McArthur GA, Chapman PB, Robert C, Larkin J, Haanen JB, Dummer R, et al. Safety and efficacy of vemurafenib in BRAF(V600E) and $B R A F(V 600 K) \quad$ mutation-positive melanoma (BRIM-3): extended follow-up of a phase 3, randomised, open-label study. Lancet Oncol. 2014 Mar;15(3):323-32.

8. Flaherty L, Hamid O, Linette $G$, Schuchter L, Hallmeyer S, Gonzalez $\mathrm{R}$, et al. A single-arm, open-label, expanded access study of vemurafenib in patients with metastatic melanoma in the United States. Cancer J. 2014;20(1):1824.

9. Zaman A, Wu W, Bivona TG. Targeting oncogenic BRAF: Past, present, and future. Cancers (Basel). 2019;11(1197):1-19.

10. Shi $H$, Hugo $W$, Kong $X$, Hong $A$, Koya RC, Moriceau G, et al. Acquired resistance and clonal evolution in melanoma during BRAF inhibitor therapy. Cancer Discov. 2014 Jan;4(1):80-93.

11. Hugo W, Shi H, Sun L, Piva M, Song $\mathrm{C}$, Kong $\mathrm{X}$, et al. Non-genomic and Immune Evolution of Melanoma Acquiring MAPKi Resistance. Cell. 2015 Sep;162(6):1271-85.

12. Eroglu Z, Ribas A. Combination therapy with BRAF and MEK inhibitors for melanoma: Latest evidence and place in therapy. Ther Adv Med Oncol. 2016;8(1):48-56.

13. Robert C, Flaherty $K$, Nathan $P$, Hersey P, Garbe C, Milhem M, et al. 
Five-year outcomes from a phase 3 METRIC study in patients with BRAF V600 E/K-mutant advanced or metastatic melanoma. Eur J Cancer. 2019 Mar;109:61-9.

14. Ascierto PA, McArthur GA, Dreno B, Atkinson V, Liszkay G, Di Giacomo $\mathrm{AM}$, et al. Cobimetinib combined with vemurafenib in advanced BRAF(V600)-mutant melanoma (coBRIM): updated efficacy results from a randomised, double-blind, phase 3 trial. Lancet Oncol. 2016 Sep;17(9):1248-60.

15. Long G V., Stroyakovskiy D, Gogas $\mathrm{H}$, Levchenko $\mathrm{E}$, De Braud F, Larkin $\mathrm{J}$, et al. Combined BRAF and MEK inhibition versus BRAF inhibition alone in melanoma. $\mathrm{N}$ Engl $\mathrm{J}$ Med. 2014;371(20):1877-88.

16. Robert C, Karaszewska B, Schachter J, Rutkowski P, Mackiewicz A, Stroiakovski D, et al. Improved overall survival in melanoma with combined dabrafenib and trametinib. N Engl J Med. 2015;372(1):30-9.

17. Koller KM, Wang W, Schell TD, Cozza EM, Kokolus KM, Neves RI, et al. Malignant melanoma-The cradle of anti-neoplastic immunotherapy. Crit Rev Oncol Hematol. 2016 Oct;106:25-54.

18. Maio M, Grob J-J, Aamdal S, Bondarenko I, Robert C, Thomas L, et al. Five-year survival rates for treatment-naive patients with advanced melanoma who received ipilimumab plus dacarbazine in a phase III trial. J Clin Oncol. 2015 Apr;33(10):1191-6.

19. Schadendorf D, Hodi FS, Robert C, Weber JS, Margolin K, Hamid O, et al. Pooled Analysis of Long-Term Survival Data From Phase II and Phase III Trials of Ipilimumab in Unresectable or Metastatic Melanoma. J Clin Oncol. 2015 Jun;33(17):1889-14.

20. Horvat TZ, Adel NG, Dang T-O, Momtaz P, Postow MA, Callahan MK, et al. Immune-Related Adverse Events, Need for Systemic Immunosuppression, and Effects on Survival and Time to Treatment Failure in Patients With Melanoma
Treated With Ipilimumab at Memorial Sloan Kettering Cancer Center. J Clin Oncol. 2015 Oct;33(28):3193-8.

21. Ribas A, Puzanov I, Dummer R, Schadendorf D, Hamid O, Robert C, et al. Pembrolizumab versus investigator-choice chemotherapy for ipilimumab-refractory melanoma (KEYNOTE-002): a randomised, controlled, phase 2 trial. Lancet Oncol. 2015 Aug;16(8):908-18.

22. Weber JS, D'Angelo SP, Minor D, Hodi FS, Gutzmer R, Neyns B, et al. Nivolumab versus chemotherapy in patients with advanced melanoma who progressed after anti-CTLA-4 treatment (CheckMate 037): a randomised, controlled, open-label, phase 3 trial. Lancet Oncol. 2015 Apr;16(4):375-84.

23. Robert $\mathrm{C}$, Long $\mathrm{G} \vee$, Brady $\mathrm{B}$, Dutriaux C, Maio M, Mortier L, et al. Nivolumab in previously untreated melanoma without BRAF mutation. $N$ Engl J Med. 2015 Jan;372(4):320-30.

24. Ribas A, Hamid O, Daud A, Hodi FS, Wolchok JD, Kefford R, et al. Association of Pembrolizumab With Tumor Response and Survival Among Patients With Advanced Melanoma. JAMA. 2016 Apr;315(15):1600-9.

25. Weber JS, Hodi FS, Wolchok JD, Topalian SL, Schadendorf D, Larkin $J$, et al. Safety Profile of Nivolumab Monotherapy: A Pooled Analysis of Patients With Advanced Melanoma. J Clin Oncol. 2017 Mar;35(7):78592.

26. Schachter J, Ribas A, Long $G \vee$, Arance A, Grob J-J, Mortier L, et al. Pembrolizumab versus ipilimumab for advanced melanoma: final overall survival results of a multicentre, randomised, open-label phase 3 study (KEYNOTE-006). Lancet (London, England). 2017 Oct;390(10105):1853-62.

27. Wolchok JD, Chiarion-Sileni V, Gonzalez R, Rutkowski P, Grob JJ, Cowey CL, et al. Updated results from a phase III trial of nivolumab (NIVO) combined with ipilimumab (IPI) in treatment-naive patients 
(pts) with advanced melanoma (MEL) (CheckMate 067). J Clin Oncol. 2016 May 20;34(15 Suppl):9505.

28. Hugo W, Zaretsky JM, Sun L, Song C, Moreno BH, Hu-Lieskovan S, et al. Genomic and Transcriptomic Features of Response to Anti-PD-1 Therapy in Metastatic Melanoma. Cell. 2017 Jan;168(3):542.

29. Shin DS, Zaretsky JM, EscuinOrdinas $H$, Garcia-Diaz A, HuLieskovan S, Kalbasi A, et al. Primary Resistance to PD-1 Blockade Mediated by JAK1/2 Mutations. Cancer Discov. 2017 Feb;7(2):188-201.

30. Zaretsky JM, Garcia-Diaz A, Shin DS, Ordinas HE-, Hugo W, Hu-
Lieskovan S, et al. Mutations Associated with Acquired Resistance to PD-1 Blockade in Melanoma. N Engl J Med. 2016;375(9):819-29.

31. Amaria RN, Menzies AM, Burton EM, Scolyer RA, Tetzlaff MT, Antdbacka R, et al. Neoadjuvant systemic therapy in melanoma: recommendations of the International Neoadjuvant Melanoma Consortium. Lancet Oncol. 2019 Jul;20(7):e378-89.

32. van Zeijl MCT, van den Eertwegh AJ, Haanen JB, Wouters MWJM. (Neo)adjuvant systemic therapy for melanoma. Eur J Surg Oncol. 2017 Mar;43(3):534-43. 